\title{
RESEARCH PAPER \\ Phosphorus sources enriched with filter cake and microorganisms in the soil microbiota: Phosphorus absorption and sugar cane dry matter production
}

\author{
Alfredo R. Hernández'1, Renato de M. Prado², Leónides C. González \\ Gustavo Caione ${ }^{4}$, Leandro R. Moda ${ }^{2}$, Luis C. Assis ${ }^{2}$, and Hilário J. Almeida ${ }^{2}$ \\ 'Facultad Agropecuaria de Montaña del Escambray, Universidad de Sancti Spiritus "José Martí Pérez" \\ (FAME/UNISS). Cuba. \\ ${ }^{2}$ Faculdade de Ciências Agrárias e Veterinárias, Universidade Estadual Paulista (FCAV/UNESP). Via de \\ acesso Prof. Paulo Castellane, s/n, CEP 14.884-900, Jaboticabal, SP, Brazil. \\ ${ }^{3}$ Centro de Estudios para la Transformación Agraria Sostenible (CETAS). Facultad de Ciencias Agrarias. \\ Universidad de Cienfuegos. Carretera a Rodas km 4 Cuatro Caminos CP 59430, Cuba. \\ ${ }^{4}$ Universidade do Estado de Mato Grosso, Câmpus Universitário de Alta Floresta. Av. Perimetral Rogério \\ Silva, s/n-Jardim Flamboyant, CEP 78580-000, Alta Floresta, MT, Brazil.
}

\begin{abstract}
A.R. Hernández, R.M. Prado, L.C. González, G. Caione, L.R. Moda, L.C. Assis, and H.J. Almeida. 2015. Phosphorus sources enriched with filter cake and microorganisms In the soil microbiota: Phosphorus absorption and sugar cane dry matter production. Cien. Inv. Agr. 42(2):295-303. Filter cake enriched with biofertilizer (associated with fertilizer phosphate) can increase the available phosphorus, and thus improve the absorption of phosphorus and dry matter accumulation by plants. The objective of this study was to evaluate the effect of phosphorus sources in the absence and presence of filter cake (enriched with biofertilizer or not enriched) on the soil population of microorganisms, soil phosphorus content, phosphorus accumulation in the aerial portion of the plant and production of dry matter in sugar cane plants. The experiment was performed in a greenhouse using sugar cane as the test plant. A completely randomized design was adopted with a $3 \times 3+1$ factorial arrangement and three repetitions. The treatments consisted of the application of three phosphorus sources $\left(50 \mathrm{mg} \mathrm{dm}^{-3}\right.$ of $\mathrm{P}$, soluble in citric acid), (i.e., triple superphosphate, reactive phosphate of Bayóvar ${ }^{\circledR}$ and natural phosphate of Araxá), combined with three filter cake treatments (enriched/not enriched with biofertilizer and no filter cake as a control). The experimental unit consisted of a pot $\left(20 \mathrm{dm}^{3}\right)$ filled with samples of an Oxisol soil containing two plants. Ninety days after the transplantation, samples were evaluated in terms of the soil phosphorus content and the populations of bacteria, fungus and phosphate solubilizer microorganisms. After one hundred and twenty days, the production of dry mass and accumulation of phosphorus were evaluated. The triple superphosphate associated with filter cake enriched with biofertilizer stood out relative to the use of cake only in terms of increasing the phosphorus content in the soil, the phosphorus accumulation in the plant and the dry mass production in sugar cane plants.
\end{abstract}

Key words: Agricultural waste, organic-fertilizer, phosphate fertilizer, Saccharum spp. 


\section{Introduction}

Despite the biological importance of phosphorus (P) for sugar cane (Bahadur et al., 2002), the amount absorbed by the plant is relatively low and reaches $18 \mathrm{~kg}$ of $\mathrm{P}$ for production of $100 \mathrm{t}$ of sugar cane (fresh matter) (Orlando Filho, 1993). In addition, the amount of phosphate fertilizers used in sugar cane production is high due to the low availability of $\mathrm{P}$ in a given soil, which is caused by high adsorption of this nutrient in tropical soils.

Fertilization with the use of biofertilizers is an alternative intended to increase the availability of $\mathrm{P}$ in the soil. Certain authors claim that this technology is low cost and can improve the $\mathrm{P}$ content in the soil (Chen et al., 2006) and increase both absorption by the plants and productivity (Stamford et al., 2006). Under these conditions, use of biofertilizers reduces dependence on chemical fertilization by half (Mahfouz and Sharaf-Eldin, 2007).

In Brazil, several papers have addressed P studies in sugar cane under different edaphoclimatic conditions (Korndörfer and Melo, 2009; Santos et al., 2009; Santos et al., 2010; Almeida Júnior et al., 2011; Caione et al., 2013) with different results on productivity of this crop. One of the alternative $\mathrm{P}$ sources for sugar cane is filter cake, which includes phosphorus in its chemical composition, although it is necessary to enrich it with a chemical fertilizer. The application of filter cake together with the mineral phosphate fertilizer was shown to increased sugar productivity in ultisol (Santos et al., 2011), thus demonstrating the potential of this treatment as a partial substitute for chemical phosphate fertilizer.

Several reports have addressed the use of populations of phosphate solubilizer microorganisms in different crop systems and soil types and reported great potential for fungi and bacteria (Nahas et al., 1994a). Thus, use of microorganisms associated with phosphorus sources could contribute to improving the efficiency of alternative sources of P (Mendes and Reis Júnior, 2003). Proper management of organic-mineral phosphate fertilization in sugar cane crops appears to be important for sustainable production. However, little is known about the effects of these materials on soil microbiota and plant nutrition. Our objective is to verify the effects of phosphate fertilization (regardless of the source) associated with filter cake enriched with microorganisms (compared with non-enriched filter cake). These effects allegedly favor the activity of soil microbiota, augment the P content of soil, and affect absorption by the plant and thus dry matter production.

Using the previously mentioned criteria as a starting point, we aim to evaluate the effect of phosphorus sources in the absence and presence of filter cake that is enriched or not enriched with biofertilizers on the soil population microorganisms, soil phosphorus content, phosphorus accumulation in the aerial portion of the plant and production of dry matter in sugar cane plants.

\section{Materials and methods}

The experiment was performed in a greenhouse using sugar cane variety CTC 5 as an indicator plant. The experimental units consisted of $20 \mathrm{dm}^{3}$ pots $(29 \mathrm{~cm}$ in diameter and $37 \mathrm{~cm}$ in height), filled with samples of an Oxisol soil containing two plants. Soil was collected (in a layer $20-60 \mathrm{~cm}$ deep) and sieved (2 $\mathrm{mm}$ ), and chemical analysis was performed to assess fertility characteristics, according to the methodology described by Raij et al. (2001). The chemical attributes were measured as follows: $\mathrm{pH}\left(\mathrm{CaCl}_{2}\right)=4.5, \mathrm{MO}=6 \mathrm{~g} \mathrm{dm}^{-3}, \mathrm{P}$ $\left(\right.$ resin) $=1 \mathrm{mg} \mathrm{dm}{ }^{-3}, \mathrm{~K}=1.4 \mathrm{mmol}_{\mathrm{c}} \mathrm{dm}^{-3}, \mathrm{Ca}=$ $10 \mathrm{mmol}_{\mathrm{c}} \mathrm{dm}^{-3}, \mathrm{Mg}=7 \mathrm{mmol}_{\mathrm{c}} \mathrm{dm}^{-3}, \mathrm{H}+\mathrm{Al}=28$ $\mathrm{mmol}_{\mathrm{c}} \mathrm{dm}^{-3}$, cation exchange capacity $(\mathrm{CTC})=$ $46.4 \mathrm{mmol}_{\mathrm{c}} \mathrm{dm}^{-3}$ and base saturation $(\mathrm{V})=40 \%$. Next, soil liming was performed 30 days before planting to raise the soil base saturation to $60 \%$. 
Treatments were arranged in one $3 \times 3+1$ factorial scheme with three sources of phosphorus (i.e., triple superphosphate $\left(\mathrm{P}_{2} \mathrm{O}_{5}\right.$ soluble in citric acid $\left.=41 \%\right)$, reactive phosphate of Bayóvar ${ }^{\circledR}$ (citric acid soluble $\mathrm{P}_{2} \mathrm{O}_{5}=14 \%$ ) and natural phosphate of Araxá (soluble $\mathrm{P}_{2} \mathrm{O}_{5}=4 \%$ citric acid)), three filter cake treatments (i.e., filter cake enriched with microorganisms from Biopack biofertilizer, a non-enriched organic residual filter cake, and only phosphorus sources, without the enrichment with cake and microorganisms) and a control treatment, without cake and phosphorus sources. A completely randomized design was used with three repetitions.

A dose of $50 \mathrm{mg} \mathrm{dm}^{-3} \mathrm{P}$-soluble citric acid was used for all phosphorus sources. The dose of composted filter cake applied in the pots corresponded to $30 \mathrm{t} \mathrm{ha}^{-1}$ on a dry basis. The enriched organic compound was obtained by composting the filter cake with the addition of the biofertilizer Biopack ${ }^{\circledR}$, which contains composed natural polysaccharide organic acids of low molecular weight, humate, purified phosphate, apatite and selected microorganisms $\left(1 \times 10^{-6}\right.$ colonies $\mathrm{cm}^{-3}$ of the product added to $480 \mathrm{~mL} \mathrm{~kg}^{-1}$ of cake). The biofertilizer was activated by a flow of air for 24 $\mathrm{h}$ prior to application in the presence of $0.4 \mathrm{~kg}$ of filter cake per liter of water.

Chemical analysis of the filter cake was performed to determine the overall level of macronutrients using the methodology described by Battaglia et al. (1983) and the following values were found: $\mathrm{N}=1.40 \%, \mathrm{P}=1.17 \%, \mathrm{~K}=0.22 \%, \mathrm{Ca}=2.74 \%$, $\mathrm{Mg}=1.08 \%, \mathrm{~S}=0.24 \%$, and $\mathrm{C} / \mathrm{N}=12 / 1$. Microbiological characterization of the filter cake was performed using the serial dilution method. Cultivation was performed on the medium of Bunt and Rovira (1955) to count the total bacteria, on the medium of Martin (1950) to count fungi, and on Pikoskaya medium (Martinez et al., 2006) to count phosphate solubilizing bacteria. The populations obtained for the total bacterial count, phosphate solubilizing microorganisms and fungi totaled $2.97 \times 10^{5}, 2.5 \times 10^{2}$ and $2.5 \times$ $10^{3} \mathrm{cfu} \mathrm{g}^{-1}$, respectively.
Nitrogen (200 $\left.\mathrm{mg} \mathrm{dm}^{-3}\right)$ in the form of ammonium sulfate $(20 \% \mathrm{~N})$ and potassium $\left(150 \mathrm{mg} \mathrm{dm}^{-3}\right)$ in the form of potassium chloride $\left(60 \% \mathrm{~K}_{2} \mathrm{O}\right)$ were applied uniformly in all treatments. Treatments without filter cake were equilibrated with nutrients according to the amount present in the cake. After filling the pots with the proper treatments, they were left for five days under regular irrigation, and two sugar cane plants per pot were transplanted. To obtain the plants, yolks of approximately 4 $\mathrm{cm}$ were cut and placed in polypropylene pots containing washed sand for sprouting. When the plants reached a height of approximately $15 \mathrm{~cm}$, they were transplanted to the pots. Irrigation was supplied daily, and moisture was maintained between $60 \%$ and $70 \%$ of the water holding capacity.

At 90 days after transplantation, soil samples were collected from each pot to determine the phosphorus content according to the methodology described by Raij et al. (2001). Soil samples were also collected at the same time for microbiological evaluation. The samples were packed in plastic bags, protected from light and held in coolers until they were brought to the laboratory, where they were immediately sieved ( $2 \mathrm{~mm}$ in diameter) and maintained between $50 \%$ and $60 \%$ of field capacity at $40^{\circ} \mathrm{C}$ (Cardoso et al., 2009). To count microorganisms (total bacteria, phosphate solubilizing microorganisms, and total fungus), the same methodology was used as described for the analysis of filter cake. The colonies were assessed using a colony counter with $6 x$ enlargement.

At 120 days after the installation of the experiment, the sugar cane shoots were cut. The plant materials (shoots and roots) were washed and placed in an oven $\left(65^{\circ} \mathrm{C}\right)$ until they reached a constant weight to determine the dry matter content. Samples of the aerial portions were ground for chemical analysis of the phosphorus content according to the methodology described by Battaglia et al. (1983). Using data from the level of phosphorus in the dry matter of shoots and the total dry matter of the aerial portion for each pot, the total phosphorus accumulation per pot was calculated. 
Data were submitted to variance analysis according to the experimental design. Means were compared using Tukey's test $(\mathrm{P} \leq 0.05)$ via the ASSISTAT statistical software. For populations of microorganisms, variance analysis was performed based on the log transformed data.

\section{Results}

The statistical analysis revealed significant interactions among sources of $\mathrm{P}$ and filter cake for the $\mathrm{P}$ content in the soil, $\mathrm{P}$ accumulation in the aerial portion, aerial dry mass accumulation, root dry mass and total dry mass (Table 1). The phosphate solubilizer microorganisms, total bacteria and fungi populations were affected by only the filter cake factor.

Fewer colony forming units of phosphate solubilizer microorganisms, total bacteria and fungi were observed in the absence of the filter cake (Table 2). The enrichment of the filter cake increased the population of phosphate solubilizer microorganisms.

The use of the triple superphosphate provided a higher soil $\mathrm{P}$ content, which was similar in the absence of filter cake and in the presence of enriched and non-enriched cake (Table 3). The phosphate of Araxá produced decreased the contents of the nutrient in the soil for all cake forms. The effect of the filter cake inside the sources of $\mathrm{P}$ was higher for the treatments with enriched cake, followed by the treatments with cake but without enrichment, regardless of the source of P used.

The largest accumulation of $\mathrm{P}$ in the aerial portion of the sugar cane occurred with the use of $\mathrm{P}$ in the form of triple superphosphate, either in the absence or presence of enriched filter cake. However, the results from triple superphosphate associated with non-enriched filter cake did not differ from those of the other sources of P (Table 3). The application of the enriched cake promoted higher accumulation of $\mathrm{P}$ in the aerial portion of the plant, regardless of the source of P used.

The use of the triple superphosphate promoted higher production of dry mass of the sugar cane (aerial portion, root and complete plant) in the absence of filter cake treatments and with enriched cake; however, for combinations among $\mathrm{P}$ sources with cake and without biofertilizers, the phosphate of Araxá produced results that were similar to that of the triple superphosphate (Table 4). The use of the enriched filter cake provided higher production of dry mass (aerial portion, root and complete plant) for the three sources of $\mathrm{P}$ used, followed by application of the cake without enrichment.

Table 1. Values of $\mathrm{F}$ and significance level for the population of phosphate solubilizer microorganisms (PSM), total bacteria (TB), total fungi (TF), phosphorus in the soil (P), phosphorus accumulation (PA), dry mass accumulation of the aerial portion (DMA), dry mass accumulation of the roots (DMR) and total dry mass (TDM) as a function of phosphorus sources in the presence of filter cake (enriched or non-enriched).

\begin{tabular}{lcccccccc}
\hline Factors & PSM & TB & TF & P & PA & DMA & DMR & TDM \\
\hline Sources of P & $0.19 \mathrm{~ns}$ & $0.01 \mathrm{~ns}$ & $1.96 \mathrm{~ns}$ & $408.53^{* *}$ & $16.07^{* *}$ & $17.79^{* *}$ & $17.81^{* *}$ & $17.81^{* *}$ \\
Filter cake & $46.16^{* *}$ & $20.98^{* *}$ & $94.34^{* *}$ & $770.40^{* *}$ & $317.72^{* *}$ & $195.15^{* *}$ & $195.2^{* *}$ & $195.16^{* *}$ \\
Sources $\times$ cake & $1.26 \mathrm{~ns}$ & $0.86 \mathrm{~ns}$ & $1.69 \mathrm{~ns}$ & $31.26^{* *}$ & $7.53^{* *}$ & $4.95^{* *}$ & $4.98^{* *}$ & $4.95^{* *}$ \\
Fact. $\times$ control. & $41^{* *}$ & $1.93 \mathrm{~ns}$ & $7.4^{*}$ & $1541.6^{* *}$ & $459.92^{* *}$ & $517.23^{* *}$ & $517.2^{* *}$ & $517.24^{* *}$ \\
CV $(\%)$ & 6.2 & 4.0 & 7.0 & 3.6 & 2.7 & 6.1 & 7.1 & 6.6 \\
\hline
\end{tabular}

$* *, *$ and ns: Significant at $1 \%$ and $5 \%$ error probability and non-significant, respectively $(\mathrm{P} \geq 0.05)$; Fact. $\times$ control: Factorial $\times$ control.

CV: Coefficient of Variation. 
Table 2. Population of phosphate solubilizer microorganisms, total bacteria and fungi in the soil as a function of phosphorus sources in the presence of enriched filter cake or non-enriched filter cake.

\begin{tabular}{|c|c|c|c|}
\hline Factors & $\begin{array}{l}\text { Phosphate solubilizer microorganisms } \\
\qquad \mathrm{CFU} \times 10^{4} \mathrm{~g}^{-1} \text { dry soil }\end{array}$ & $\begin{array}{c}\text { Total bacteria } \\
\mathrm{CFU} \times 10^{6} \mathrm{~g}^{-1} \text { dry soil }\end{array}$ & $\begin{array}{c}\text { Total fungi } \\
\text { CFU } \times 10^{3} \mathrm{~g}^{-1} \text { dry soil }\end{array}$ \\
\hline \multicolumn{4}{|l|}{ Sources of $\mathrm{P}$} \\
\hline Triple Superphosphate & $4.06 \mathrm{a}$ & $5.60 \mathrm{a}$ & $3.83 \mathrm{a}$ \\
\hline Reactive phosphate of Bayóvar ${ }^{\circledR}$ & $4.13 \mathrm{a}$ & $5.63 \mathrm{a}$ & $3.60 \mathrm{a}$ \\
\hline Natural phosphate of Araxá & $4.07 \mathrm{a}$ & $5.62 \mathrm{a}$ & $3.77 \mathrm{a}$ \\
\hline \multicolumn{4}{|l|}{ Filter cake } \\
\hline No filter cake & $3.48 \mathrm{c}$ & $5.23 \mathrm{~b}$ & $2.80 \mathrm{~b}$ \\
\hline Non-enriched filter cake & $4.22 \mathrm{~b}$ & $5.85 \mathrm{a}$ & $4.15 \mathrm{a}$ \\
\hline Enriched cake & $4.56 \mathrm{a}$ & $5.77 \mathrm{a}$ & $4.22 \mathrm{a}$ \\
\hline Factorial media & $4.09 \mathrm{a}$ & $5.62 \mathrm{a}$ & $3.73 \mathrm{a}$ \\
\hline Control media & $3.13 \mathrm{~b}$ & $5.43 \mathrm{a}$ & $3.32 \mathrm{~b}$ \\
\hline
\end{tabular}

Media followed by the same letter do not differ statistically. Tukey's test was applied at the $5 \%$ level of probability. CFU: colony-forming units.

Table 3. Phosphorus content in the soil and phosphorus accumulation in the aerial portion of the sugar cane plant as a function of phosphorus sources in the presence of filter cake (enriched or non-enriched).

\begin{tabular}{|c|c|c|c|}
\hline Sources of P & Without filter cake & Non-enriched Filter cake & Enriched filter cake \\
\hline $\mathrm{P}$ in soil $\left(\mathrm{mg} \mathrm{dm}^{-3}\right)$ & & 90 days & \\
\hline Triple superphosphate & $36.0 \mathrm{cA}$ & $65.3 \mathrm{bA}$ & $76.7 \mathrm{aA}$ \\
\hline $\begin{array}{l}\text { Reactive phosphate of } \\
\text { Bayóvar }^{\circledR}\end{array}$ & $28.0 \mathrm{cB}$ & $52.7 \mathrm{bB}$ & $57.3 \mathrm{aB}$ \\
\hline Natural phosphate of Araxá & $18.0 \mathrm{cC}$ & $39.7 \mathrm{bC}$ & $47.6 \mathrm{aC}$ \\
\hline \multicolumn{4}{|l|}{$\mathrm{P}$ accumulation (mg per pot) } \\
\hline Triple superphosphate & $198.6 \mathrm{cA}$ & $289.7 \mathrm{bAB}$ & $427.1 \mathrm{aA}$ \\
\hline $\begin{array}{l}\text { Reactive phosphate of } \\
\text { Bayóvar }^{\circledR}\end{array}$ & $148.2 \mathrm{cB}$ & $262.4 \mathrm{bB}$ & $350.5 \mathrm{aB}$ \\
\hline Natural phosphate of Araxá & $109.9 \mathrm{cB}$ & $312.3 \mathrm{bA}$ & $383.3 \mathrm{aB}$ \\
\hline
\end{tabular}

Capital letters compare the phosphorus sources inside of the cake (in columns), and small letters compare the cake inside of each phosphorus source (in the line).

\section{Discussion}

The increase in the population of microorganisms in the soil with the use of one organic residue (Table 2) was also verified in soil cultivated with rice, which resulted in higher populations of bacteria and fungi and higher microbial activity than in the control or treatments with chemical fertilizers (Zhang et al., 2012). Nahas et al. (1994b) also verified an increase of the number of fungi with the addition of organic matter (milled straw of corn) relative to treatment with only the application of phosphate rock in an Oxisol. Therefore, the use of an organic residue is essential for the growth of the microbial populations in the soils (Krey et al., 2013). The fact that the population of phosphate solubilizer microorganisms in filter cake enriched with Biopack was increased can be attributed to the presence of this type of microorganism in the biofertilizer.

The greater contents of $\mathrm{P}$ in the soil obtained with the triple superphosphate for all cake forms (Table 3) show the importance of the application of $\mathrm{P}$ via this source. This increment could be caused by the different physical and chemical characteristics of the fertilizers. Because the triple superphosphate is supplied in granulated 
Table 4. Dry mass of the aerial portion, root and the complete plant of the sugar cane as a function of the use of phosphorus sources in the presence of filter cake enriched with microorganisms or non-enriched filter cake.

\begin{tabular}{|c|c|c|c|}
\hline \multirow[b]{2}{*}{ Sources of P } & Without filter cake & Non-enriched Filter cake & Enriched filter cake \\
\hline & \multicolumn{3}{|c|}{ 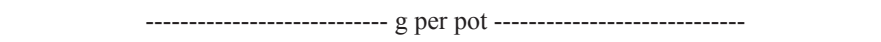 } \\
\hline \multicolumn{4}{|l|}{ Aerial part } \\
\hline Triple superphosphate & $88.6 \mathrm{bA}$ & $101.1 \mathrm{bAB}$ & 145.9 aA \\
\hline Reactive phosphate of Bayóvar ${ }^{\circledR}$ & $70.2 \mathrm{cB}$ & $89.1 \mathrm{bB}$ & $127.7 \mathrm{aB}$ \\
\hline Natural phosphate of Araxá & $59.93 \mathrm{cB}$ & $103.3 \mathrm{bA}$ & $125.9 \mathrm{aB}$ \\
\hline \multicolumn{4}{|l|}{ Roots } \\
\hline Triple superphosphate & $101.2 \mathrm{bA}$ & $113.7 \mathrm{bAB}$ & $158.5 \mathrm{aA}$ \\
\hline Reactive phosphate of Bayóvar ${ }^{\mathbb{B}}$ & $82.8 \mathrm{cB}$ & $101.7 \mathrm{bB}$ & $140.3 \mathrm{aB}$ \\
\hline Natural phosphate of Araxá & $72.5 \mathrm{cB}$ & $115.9 \mathrm{bA}$ & $138.5 \mathrm{aB}$ \\
\hline \multicolumn{4}{|l|}{ Complete plant } \\
\hline Triple superphosphate & $189.7 \mathrm{bA}$ & $214.8 \mathrm{bAB}$ & $304.3 \mathrm{aA}$ \\
\hline Reactive phosphate of Bayóvar ${ }^{\circledR}$ & $152.9 \mathrm{cB}$ & $190.8 \mathrm{bB}$ & $268.1 \mathrm{aB}$ \\
\hline Natural phosphate of Araxá & $132.5 \mathrm{cB}$ & $219.1 \mathrm{bA}$ & $264.4 \mathrm{aB}$ \\
\hline
\end{tabular}

Capital letters compare the phosphorus sources inside of the cake (in columns), and small letters compare the cake inside of each phosphorus source (in lines).

form, it might have suffered smaller losses due to adsorption with the clay fraction relative to the natural phosphate treatments that are floured and thus have a larger contact surface.

The increase in $\mathrm{P}$ contents in the soil with the use of the enriched cake, regardless of the source of P used (Table 3), shows that despite the existing doubts as to whether the phosphate solubilizer microorganisms would be sufficient to substantially increase the amount of $\mathrm{P}$ in the soil (Richardson, 2001; Richardson et al., 2009), this result demonstrates the agronomic potential of those microorganisms.

It is important to highlight that the $\mathrm{P}$ content in the soil rose by $3.3 \mathrm{mg} \mathrm{dm}^{-3}$ of $\mathrm{P}$ in the control- treatment (Table 2) to $76.7 \mathrm{mg} \mathrm{dm}^{-3}$ of $\mathrm{P}$ in the treatment with triple superphosphate associated with enriched filter cake (Table 3). This effect is attributed to the use of the filter cake in the fertilization, which contributed to reducing the adsorption processes of $\mathrm{P}$, as proven by other authors, e.g., Santos et al. (2010) and Almeida Júnior et al. (2011). Additionally, it is important to take into account the $\mathrm{P}$ content contained in the filter cake (1.17\%), and the applied dose $\left(30 \mathrm{t} \mathrm{ha}^{-1}\right)$ corresponding to $175 \mathrm{mg}$ $\mathrm{dm}^{-3}$ of P. However, not all of the P would be totally available, and thus, the mineralization process is necessary.

Therefore, the importance of the filter cake combined with soluble phosphate as source of $\mathrm{P}$ has been demonstrated, which is in agreement with the work of Santos et al. (2010), who stated that the cake offers potential as a substitute for a portion of the chemical fertilizers. The increase of the P content in the soil with the use of filter cake was also verified by Santos et al. (2009), who evaluated $\mathrm{P}$ sources in ultisol.

The greater accumulation of $\mathrm{P}$ in the aerial portions of the plants promoted by the enriched cake reflects the higher contents of $\mathrm{P}$ in the soil in the presence of the enriched cake (Table 3), an effect that might have occurred due to the increase in the population of phosphate solubilizer microorganisms with the use this treatment (Table 2). Further studies will be necessary to evaluate the effects of triple superphosphate with enriched filter cake under field conditions. 
A factor that could cause divergent results in the different assays is synchronization among the liberation of $\mathrm{P}$ by the microorganisms and the absorption by the plants. Additionally, the soil is a highly complex medium that could have regulatory effects related to biotic factors (Mendes and Reis Júnior, 2003). Van Veen (1997) states that the main biotic factors that can limit the efficiency of the healthy use of microorganisms are predation for protozoa, competition with native populations for organic substratum and competition for shelter in the soil where microorganisms can be protected against predator attacks. Among the non-biotic factors, the following should be mentioned: clay type, texture of the soil, temperature, $\mathrm{pH}$ and availability of organic substratum.

The greater dry mass accumulation observed with the use of the triple superphosphate (Table 4) is in agreement with the data observed for the content of $\mathrm{P}$ in the soil and accumulation by the plant (Table 3 ), demonstrating the largest efficiency of this source. The beneficial effect of the use of triple superphosphate sources in the production of the sugar cane was also observed by Santos et al. (2009).

The greater dry mass accumulation provided by the enriched filter cake (Table 4 ) reflects the largest content of $\mathrm{P}$ in the soil and accumulation of $\mathrm{P}$ in the aerial portion of the plants (Table 3) with this treatment. In general, papers report different organic compounds and biofertilizers associated with phosphate fertilizer that also prove the benefits on the availability of $\mathrm{P}$ in the soil and the productivity of sugar cane (Shankaraiah et al., 2000; Stamford et al., 2006).

\section{Resumen}

A.R. Hernández, R.M. Prado, L.C. González, G. Caione, L.R. Moda, L.C. Assis y H.J. Almeida. 2015. Fuentes de fósforo enriquecidas con cachaza y microorganismos en la microbiota del suelo, la absorción de fósforo y la caña de azúcar en la producción de materia seca. Cien. Inv. Agr. 42(2):295-303. La cachaza enriquecida con biofertilizante asociado con fertilizantes de fosfato pueden aumentar el fósforo disponible, la absorción por las plantas y la acumulación de materia seca. Este trabajo tuvo como objetivo evaluar el efecto de fuentes de fósforo enriquecidas o no con cachaza y microorganismos en la población de microorganismos del suelo, la disponibilidad de fósforo en el suelo, acumulación de fósforo en la parte aérea de la planta y la producción de materia seca en las plantas de caña de azúcar. El experimento fue desarrollado en invernadero, con la prueba de la planta de caña de azúcar. Se adoptó un diseño experimental completamente aleatorizado, con tres repeticiones en arreglo factorial $3 \times 3+1$. Los tratamientos consistieron en la aplicación de tres fuentes de fósforo $\left(50 \mathrm{mg} \mathrm{dm}^{-3} \mathrm{de} \mathrm{P}\right.$, solubles en ácido cítrico): superfosfato triple, fosfato reactivo Bayóvar ${ }^{\circledR}$ y fosfato natural de Araxá, combinadas con la cachaza enriquecida con biofertilizante o no enriquecida, sin cachaza y el tratamiento control. La unidad experimental consistió de macetas $\left(20 \mathrm{dm}^{3}\right)$, llenadas con muestras de un Oxisol, conteniendo dos plantas. A los 90 días se evaluó el contenido de fósforo en el suelo, las poblaciones de bacterias y de hongos y los microorganismos solubilizadores de fosfato. A los 120 días se avaluó la producción de materia seca y acumulación de fósforo. El superfosfato triple asociado con la torta de filtro enriquecido con biofertilizante se destacó en relación con el uso de solo la torta, aumentando el contenido de fósforo en el suelo, la acumulación de fósforo para la planta y la producción de masa seca en las plantas de caña de azúcar.

Palabras clave: Fertilizantes de fosfato, fertilizantes orgánico, residuos agrícolas, Saccharum spp. 


\section{References}

Almeida Júnior, A.B., C.W.A. Nascimento, M.F. Sobral, F.B.V. Silva, and W.A. Gomes. 2011. Fertilidade do solo e absorção de nutrientes em canade-açúcar fertilizada com torta de filtro. Rev. Bras. Eng. Agric. Ambient. 15: 1.004-1.013.

Bahadur, M.M., M. Ashrafuzzaman, M.A. Kabir, M.F. Chowdhury, and A.N. Majumder. 2002. Response of chickpea (Cicer arietinum L.) varieties to different levels of phosphorus. Crop Research 23: 293-299.

Bataglia, O.C., A.M.C. Furlani, J.P.F. Teixeira, P.R. Furlani, and J.R. Gallo. 1983. Métodos de análise química de plantas. Campinas: Instituto Agronômico. Boletim Técnico 78. pp. 48.

Bunt, J.S., and A.D. Rovira. 1995. Microbiological studies of some subantartic soils. J. Soil Science 6: 119-128.

Chen, Y.P., P.D. Rekha, A.B. Arun, F.T. Shen, W.A. Lai, and C.C. Young. 2006. Phosphate solubilizing bacteria from subtropical soil and their tricalcium phosphate solubilizing abilities. Appl. Soil Ecol. 34: 33-41.

Caione, G., F.M. Fernandes, and A. Lange. 2013. Efeito residual de fontes de fósforo nos atributos químicos do solo, nutrição e produtividade de biomassa da cana-de-açúcar. Agrária 8: 189-196.

Cardoso, E.L., M.L.N. Silva, F.M.S. Moreira, and N. Curi. 2009. Atributos biológicos indicadores da qualidade do solo em pastagem cultivada e nativa no Pantanal. Pesqui. Agropecu. Bras. 44: 631-637.

Korndörfer, G.H., and S.P. Melo. 2009. Fontes de fósforo (fluida ou sólida) na produtividade agrícola e industrial da cana de açúcar. Ciênc. Agrotec. 33: 92-97.

Krey, T., N. Vassilev, C. Baum, and B. Eichler-Löbermann. 2013. Effects of long-term phosphorus application and plant-growth promoting rhizobacteria on maize phosphorus nutrition under field conditions. Eur. J. Soil Biol. 55: 124-130.

Mahfouz, S.A., and M.A. Sharaf-Eldin. 2007. Effect of mineral vs. biofertilizer on growth, yield, and essential oil content of fennel (Foeniculum vulgare Mill.). Int. Agrophys. 21: 361-366.
Martin, J.P. 1950. Use of acid, rose bengal, and streptomycin in the plate method for estimating soil fungi. Soil Sci. 69: 215-232.

Martínez-Viera, R., M. Lopez, F.M. Brossard, G.G. Tejeda, A.H. Pereira, Z.C. Parra, S.J. Rodríguez, and A. Alba. 2006. Procedimientos para el estudio y fabricación de Biofertilizantes bacterianos. Maracay. Venezuela. Instituto Nacional de Investigaciones Agrícolas. 88 p.

Mendes, I.C., and F.B. Reis Júnior. 2003. Microrganismos e disponibilidade de fósforo $(\mathrm{P})$ nos solos: uma análise crítica. EMBRAPA, Planaltina, 26 p.

Nahas, E., J.F. Centurion, and L.C. Assis. 1994. Efeito das características químicas dos solos sobre os microrganismos solubilizadores de fosfato e produtores de fosfatases. R. Bras. Ci. Solo 18: 49-53.

Nahas, E., D.J. Fornasiere, L.C. Assis. 1994b. Resposta à inoculação de fungo solubilizador de fósforo em milho. Sci. Agric. 51: 463-469.

Orlando Filho, J. 1993. Calagem e adubação da cana de açúcar. In: Camara GMS, Oliveira EAM (Ed.). Produção de cana-de-açúcar. Piracicaba: FEALQ, pp. 133-146.

Raij, B van, J.C. Andrade, H. Cantarella, and J.A. Quaggio. 2001. Análise química para avaliação da fertilidade dos solos tropicais. Campinas: Instituto Agronômico, 285p.

Richardson, A.E., J. Barea, A.M. Mcneill, and C. Prigentcom Baret. 2009. Accquisition of phosphorus and nitrogen in rhizosphere and plant growth promotion by microorganisms. Plant and Soil 322: 17-24.

Richardson, A.E. 2001. Prospects for using soli microorganisms to improve the acquisition of phosphorus by plants. Aust. J. Plant Physiol. 28: 897-906.

Santos, D.H., M.A. Silva, C.S. Tiritan, J.S.S. Foloni, and F.R. Echer. 2011. Qualidade tecnológica da cana de açúcar sob adubação com torta de filtro enriquecida com fosfato solúvel. Rev. Bras. Eng. Agric. Ambient. 15: 443-449.

Santos, D.H., C.S. Tiritan, J.S.S. Foloni, and L.B. Fabris. 2010. Produtividade de cana de açúcar sob adubação com torta de filtro enriquecida com fosfato solúvel. Pesqui. Agropecu. Trop. 40: 454-461. 
Santos, V.R., G. Moura Filho, A.W. Albuquerque, J.P.V. Costa, C.G. Santos, and A.C.I. Santos. 2009. Crescimento e produtividade agrícola de cana-de-açúcar em diferentes fontes de fósforo. Rev. Bras. Eng. Agric. Ambient. 13: 389-396.

Stamford, N.P., R.A. Lima, C.R.S. Santos, and S.H.L. Dias. 2006. Rock biofertilizers with Acidithiobacillus on sugar cane yield and nutrient uptake in a Brazilian soil. Geomicrobiol. J. 23: 261-265.
Van Veen, J.A., L.S. Ovverbeek, and J.D. Van Elsas. 1997. Fate and activity of microorganisms introduced into soil. Microbiol. Mol. Biol. Rev. 61: 121-135.

Zhang, Q.C., I.H. Shamsi, D.T. Xu, G.H. Wang, X.Y. Lin, G. Jilani, N. Hussain, and A.N. Chaudhry. 2012. Chemical fertilizer and organic manure inputs in soil exhibit a vice versa pattern of microbial community structure. Applied Soil Ecol. 57: 01-08. 
